\title{
GROUND FORTIFICATIONS IN THE DEVELOPMENT OF THE PARK BEHIND THE MARINE SCHOOL IN DARŁOWO
}

\author{
Paweł Szumigała ${ }^{1}$, Piotr Urbański ${ }^{2}$, Krzysztof Markowski ${ }^{3}$, Sylwia Sosnowska ${ }^{4}$ \\ ${ }^{1}$ Paweł Szumigała, Department of Green Space and Landscape Architecture, Poznań University of Life Sciences, \\ ul. Trybunalska 40,60-325 Poznań, email: pawelszumigala@wp.pl, pawelsz@up.poznan.pl \\ ${ }^{2}$ Piotr Urbański, Department of Green Space and Landscape Architecture, Poznań University of Life Sciences, \\ ul. Trybunalska 40,60-325 Poznań, email: ktzpurb@up.poznan.pl,ktzpurb@wp.pl \\ ${ }^{3}$ Krzysztof Markowski, Department of Green Space and Landscape Architecture, \\ Poznań University of Life Sciences, ul. Trybunalska 40, 60-325 Poznań, email: bmarko@tlen.pl \\ ${ }^{4}$ Sylwia Sosnowska, Department of Green Space and Landscape Architecture, Poznań University of Life Sciences, \\ ul. Trybunalska 40,60-325 Poznań, email: s-sosnowska @wp.pl
}

\begin{abstract}
Streszczenie: W artykule przedstawiono zagadnienia związane z projektowaniem przestrzeni publicznych tj. trenów rekreacji i zieleni parkowej w kontekście istniejących fortyfikacji na przykładzie miasta Darłowa. Zaprezentowano przykładowe propozycje zagospodarowania obszarów historycznych fortyfikacji ziemnych w ramach opracowania realizacyjnego pt. Projekt zagospodarowania Parku za Szkołą Morską w Darłowie. Omówiono również wybrane zagadnienia kompozycyjne, funkcjonalno-przestrzenne, krajobrazowe i realizacyjne zawarte w dokumentacji projektowej parku. Przedstawiono wyniki prac projektowych, na postawie których przygotowano kompleksową dokumentacje techniczną. W opracowaniu zawarto ustalenia, na podstawie których istnieje możliwość zrealizowania parku miejskiego o zbliżonych, do naturalnych walorach krajobrazowych.
\end{abstract}

Słowa kluczowe: fortyfikacje ziemne, zagospodarowanie terenów, park, Darłowo

\begin{abstract}
The article presents problems related with designing public space, i.e. recreational areas and park green space in the context of existing fortifications with a case study of the town of Darłowo. It shows examples of the development of historical areas of ground fortifications as part of the project 'A Plan of Development of the Park Behind the Marine School in Darłowo'. The article also discusses selected issues related with the composition, spatial functionality, landscape and execution of the plan, included in the park design documentation. It presents the results of design work, which was used to prepare complex technical documentation. This study includes the arrangements thatcan be used to make a town park with scenic values which will be similar a natural scenery.
\end{abstract}

Key words: groundfortifications, area development, park, Darłowo

\section{INTRODUCTION}

The aim of the article is to make a synthetic presentation of the plan to develop the park with ground fortifications in Darłowo and to signal applicatory design problems and issues. Making a design in the area of a historical fortification complex involves limitations which are chiefly related with conservation requirements ${ }^{1}$ and provisions of local spatial development plans $^{2}$ (if any have been made for these areas). On the other hand, there are social needs and the client's requirements. Usually such areas are meant to be used for leisure and recreation. If the areas of historical fortifications are managed by the commune or town administration, it is much easier to plan and execute the functions available to the general public. The fortifications in Darłowo belong to the town. Therefore, at the end of 2011 the town authorities announced

1 The guidelines of the Voivodeship Conservation Officer in Koszalin were issued for the area under study at the stage of agreements about the development concept, Koszalin 2012.

2 The park area development plan is subject to The Local Spatial Development Plan for the Town of Darłowo Resolution No.XLVII/445/06 of the Town Council of Darłowoof 27 March 2006. 
a tender to make a plan of development of the park behind the Marine School in Darłowo. It was necessary to make a development plan for a selected part of the town centre in Darłowo as part of the execution plan. The plan comprised the areas located south of the Pomeranian Dukes' Castle, with preserved fragments of ground fortifications and the old town moat. Apart from the fortifications, the plan includes adjacent areas (a meadow), which are in private hands. A wide range of issues and problems concerning the existing and planned development of the areas adjacent to the area under study emerged while working on the design. Contemporary needs and trends in the development of urban space often collide with the character of development of historical areas. Usually there are problems of spatial functionality in the zones where historical areas contact contemporary urban development. In such situations the designer needs to recognise the problem skilfully and prepare the solutions which will simultaneously retain the values of historical areas and satisfy the needs of contemporary society.

\section{MATERIALAND METHODS}

We studied the park and adjacent areas. We used the following methods to recognise the area: green space inventories, photographic documentation, spatial functionality analyses, landscape and scenic analyses as well as compositional analyses of the park and surrounding areas. The analyses also included studying and recognising cartographic materials: historical maps, conservators' documentsand the current base map for designing purposes.

The area of the park is about 4 ha. The borders of the area under study are limited by Chopina Street in the north, Lutosławskiego Street in the east, the Wieprza River in the south and the fence surrounding the Marine School Complex in Darłowo in the west [Fig. 1]. Hence the name - the Park behindthe Marine School. At present the area is not developed and it is partly devastated. Near the park, northwards, there isthe Pomeranian Dukes' Castle - one of the main attractions in the town. It is a secondary closure of the view at the park and fortifications from the southeast. In the neighbourhood of the park, on the other side of Lutosławskiego Street there are commercial and service areas with large shopping facilities, like a Biedronka supermarket. The most valuable elements of the area under study are historical fortifications in the form of embankments and bastions ${ }^{3}$. They are located in the northern part of the park, near the grounds ofthe Marine School [Fig. 1]. The fortifications are in the form of an embankment with a prism-shaped vertical section. The embankment runs along a broken line consisting of three sections. In the places where the embankment line is broken there are two earthen bastions on a plan similar to deformed pentagons [Fig. 2]. The crown of the embankment construction, where an unpaved pedestrian path is located, is about $3.5 \mathrm{~m}$ higher than the adjacent area. Theembankment andbastions are covered with a relatively thick and conspicuous tree stand, which is in the form of an alley at straight fragments of the embankment [Fig. 3]. At present the tree stand is a substantial element of the town panorama and view of the Pomeranian Dukes' Castle from the southeast. Along the embankment and bastions runs a broken-lineshaped fragment of the old moat, which at present is not connected to the Wieprza River and it accumulates water flowing down from the embankments and adjacent areas. The water level in the moat changes along with the water level in the Wieprza River through permeable soil layers. At present there is a wetland stretching south of the fortifications, behind the moat. It is a perfect place of exposure for the panorama (view) of the fortifications and castle buildings in the background. In view of such significant historical conditions and spatial values of the place we prepared a concept of development of this area into a town park [Fig. 4]. The main

3 The fortifications in Darłowo could be found in Grolman's plan of 1815, which included defence of the coastal towns of Ustka, Darłowo, Kołobrzeg, Szczecin and Świnoujście (source:http://www.fort.mariwoj.pl/2020.htm). 
guideline of the composition was to retain the groundfortifications and view - exposure to the fortifications in the context of the castle and town panorama.
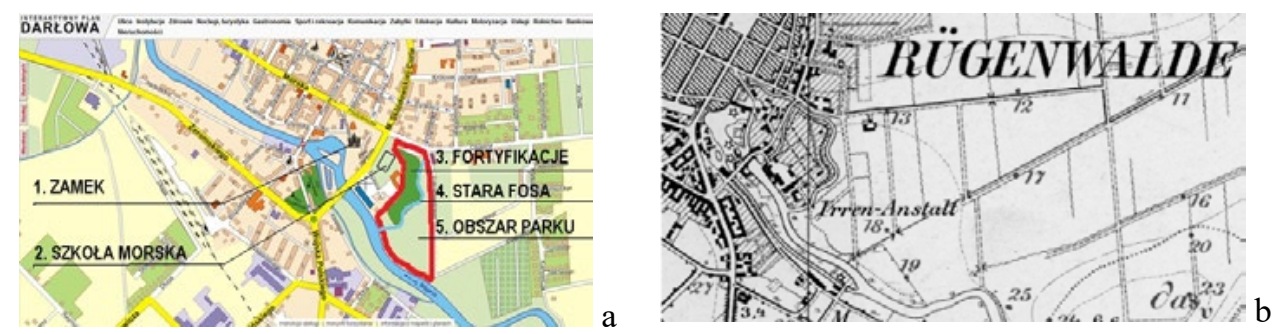

Fig. 1. A-A fragment of the present-day map of the town of Darłowo with the location of the Park behind the Marine School. Source: The authors' compilation based on www.plan.darlowo.pl, B - A fragment of an 1897 German map Agronomische Bohrungen Blatt Rügenwalde, 1:25000 - the moat, fortifications and open foreground of the fortifications are visible. Source: http: //am`zpbig.com/maps/1564_Rugenwalde_agronomische_1897.jpg

Ryc. 1. A - Fragment współczesnego planu miasta Darłowo z oznaczeniem lokalizacji Parku za Szkołą Morską. źródło: opracowanie własne z wykorzystaniem: www.plan.darlowo.pl, B - Fragment mapy niemieckiej z 1897 roku - Argonomische Bohzungen Blatt Rugenwalde. 1:25000 - widoczna fosa, fortyfikacje oraz otwarte przedpole fortyfikacji. źródło: http://amzpbig.com/maps/1564_Rugenwalde_agronomische_1897.jpg

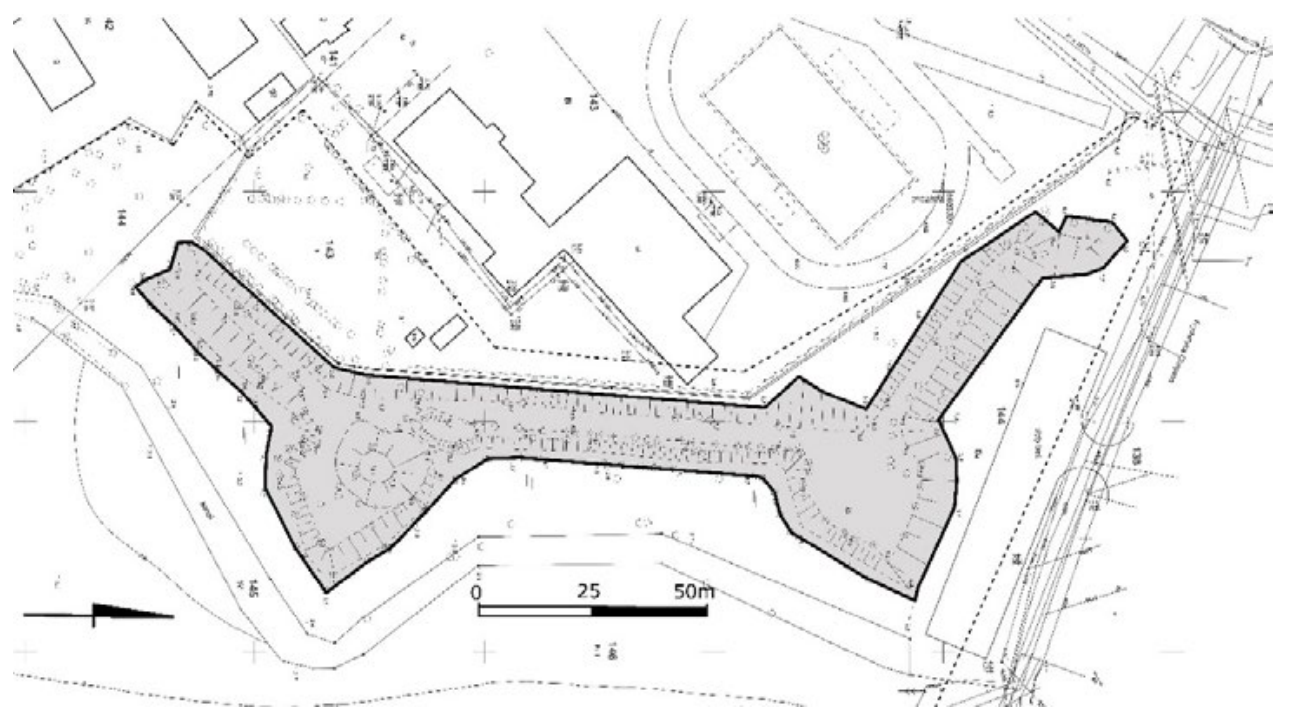

Fig. 2. An outline of the fortifications area with clearly visible bastions and fragments of the prism-shaped embankment. Source: The authors' compilation based on a fragment of a 2012 base map for planning purposes.

Ryc. 2. Obrys terenu zajmowanego przez fortyfikacje z wyraźnie widocznymi bastionami i fragmentami wału w kształcie pryzmy. źródło: opracowanie autora z wykorzystaniem fragmentu podkładu geodezyjnego do celów projektowych z 2012 r. 

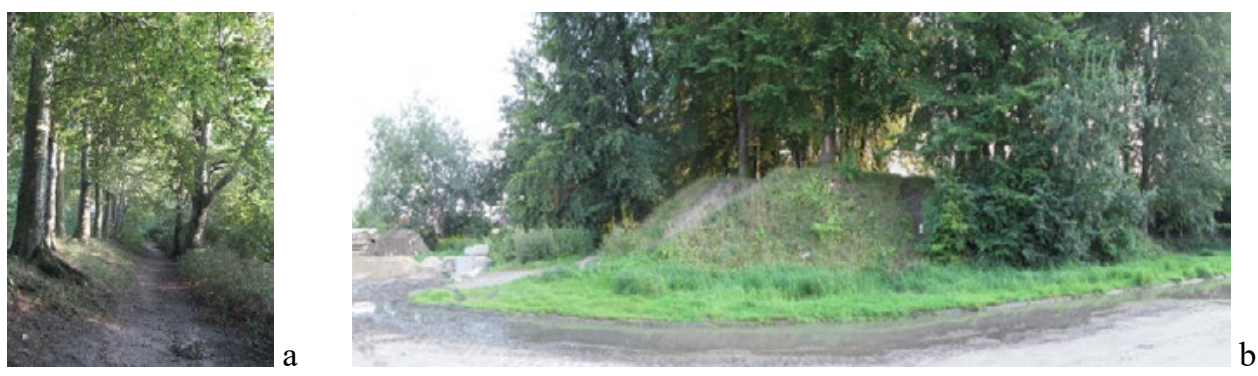

Fig. 3. A - The tree standforming an alley on the embankmentcrown, B - A view at the beginning of the embankment from Chopina Street-differences in the levels and treestand are visible. Source: The authors' photographs, summer 2012.

Ryc. 3. A - zadrzewienia korony wału w formie alei, B - widok na początek wału od strony

ul. Chopina - widoczna jest różnica poziomów i zadrzewienia. źródło: fotografie autora, lato 2012.

We planned the spatial composition of the park, consisting of a few zones with diversified leisure and recreational functions. The assumptions of the composition were based on the viewing direction from the south and east towards the fortifications and castle. For this reason, the foreground of the fortifications was planned as an open space - a meadow, which is in agreement with historical sources ${ }^{4}$. The scenic values of the place were supplemented and strengthened with a proposal to retain the tree stand on the fortifications and make new plantings of waterside green space along the existing fragment of the moat, with a species composition adjusted to the habitat conditions. In the historical part of the park (the fortifications and moat), which is protected by the conservation officer, we proposed to restore and supplement the previous arrangement of a walkway on the embankment crown with small squares on the flat surfaces of bastions. We planned to order the construction of the embankments by making geometrical corrections of the shape of the bastions as well asthe scarp slopes and edges. The aim of the ground works is to reconstruct and restore (as much as possible) the historical forms described in old documentation ${ }^{5}$.

In the remaining part of the park we planned systems of peripheral and internal paths, which allow communication in the park area and we planned to make several additional zones with a different character and function. The proposed communication system consists of pedestrian walkways and roads for pedestrian and vehicle traffic, which provide access to the following zones [Fig. 3]:

the ornamental zone - along the moat, on the side of the meadow, with a walkway running parallel to the moat.

the leisure zone - located in the historical part on the existing fortifications, connected by a footbridge with the ornamental zone on the other side of the moat. Paths running from the meadow and town, leading from the crossroads of Chopinaand Lutosławskiego Streets provide access to this zone.

the exposure zone - with a system of arched and crossing paths, which will make a network of areas to expose e.g. sculptures, installations, artistic forms, rocks andto make open-air (seasonal) exhibitions, etc.

the active recreation zone - located in the south of the park, which can be accessed from the peripheral paths, with a small triangular space at the end and another footbridge leading to Łososiowa Island, which is outside the park area, on the Wieprza River.

4 An 1893 German map of Rügenwalde.

5 The guidelines of the Voivodeship Conservation Officer in Koszalin, Koszalin 2012. 
the mass event zone - with a paved performance square in the centre of the park. It can be accessed by a footpath from the historical part and by peripheral roads or directly from the public road in Lutosławskiego Street so that vehicles can deliver equipment for performances.

the coach park zone with the entrance and exit from Chopina Street, in the place of the old car park.

the technical car park for services securing mass events (e.g. ambulances, fire brigades, etc.), located in Lutosławskiego Street.

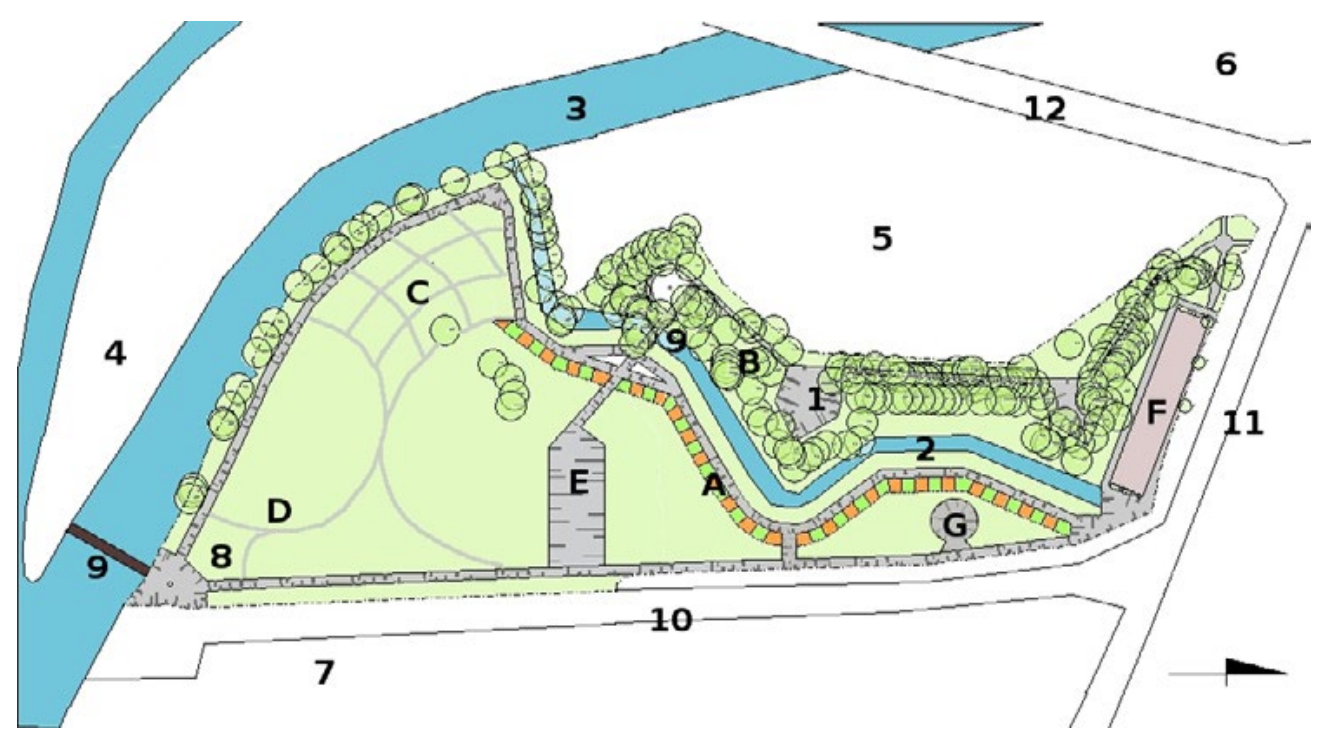

Fig. 4. Aconceptof park development. A - the ornamental zone withplantings arranged into a ribbon, $\mathrm{B}$ - the leisure zone, $\mathrm{C}$ - the exposure zone, $\mathrm{D}$ - the active recreation zone, $\mathrm{E}$ - the mass event zone, $\mathrm{F}$ - the coach park zone, $\mathrm{G}$ - the technical car park, 1 - the fortifications, 2 - the old moat, 3 - the Wieprza River, 4 - Łososiowa Island, 5 - the Marine School grounds, 6 - the area near the Pomeranian Dukes' Castle, 7 - the area near service facilities, 8 - a playground, 9 - footbridges, 10 - Lutosławskiego Street, 11 - Chopina Street, 12 - Skłodowskiej-Curie Street. Source: The authors' compilation.

Ryc. 4. Koncepcja zagospodarowania parku. A - strefa ozdobna - projektowane nasadzenia w formie wstęgi, B - strefa wypoczynkowa, C - strefa ekspozycyjna, D - strefa rekreacji czynnej, E - strefa imprez masowych, F - strefa parkowania dla autokarów, $\mathrm{G}$ - parking techniczny, 1 - fortyfikacje, 2 stara fosa, 3 - rzeka Wieprza, 4 - wyspa Łososiowa, 5 - tereny Szkoły Morskiej, 6 - rejon lokalizacji Zamku Książąt Pomorskich, 7 - rejon lokalizacji obiektów usługowych, 8 - plac zabaw, 9 - kładki, 10 - ul. Lutosławskiego, 11 - ul. Chopina, 12 - ul. M. C. Skłodowskiej. Źródło: opracowanie własne.

Each zone in the park can be accessed by technical and maintenance services by peripheral paths. They will be 4.0 metres wide and will allow vehicles with the maximum permissible laden weight of 3.5 tonnes. The peripheral paths will be paved with granite setts; the inner paths will be covered with gravel. The area located south of the moat (the meadow), which lies within the limits of the place under study, must be levelled by pouring soil to an ordinate of $+3.80 \mathrm{~m}$ (in a local coordinate system of the area under study), i.e. to the level of the pavement in Lutosławskiego Street.

The concept of park development and technical documentation received the required approval of the Voivodeship Conservation Officer in Koszalin as well as approvals from branch and administrative institutions [Szumigała P. 2012 a, b]. 


\section{RESULTS}

A plan of development of the Park behind the Marine School - selected elements.

In order to receive a permission to execute the park development plan we prepared technical documentation, which received the required approval of the Voivodeship Conservation Officer in Koszalin as well as approvals from branch and administrative institutions. The documentation includes complex and multi-branch elaborations concerning the composition, spatial functionality arrangement, green space, communication, landscape and a wide range of technical issues and detailed solutions. The documentation includes the following elements: a plan of green space development and irrigation, an inventory of green space in the entire area, a design of the irrigation system for vegetation, a design of the water aeration system, a design of the lighting system with a design of the power supplying network to illuminate the area and supply power to the irrigation appliances, a design of the pedestrian and car traffic system to provide access to vehicles of technical and maintenance services, a design of street furniture, playgrounds and artistic spatial structures, investment staging and spatial visualisations of design solutions.

In further sections of the article there are brief presentations of selected, substantial elements of the development plan included in the park design documentation, which show the connections and the context of existing fortifications and park development plan.

Inventory

220 items (trees and shrub groups) were inventoried in the area under study. Deciduous trees are predominant. Some of the most common species are: the common beech (Fagus sylvatica L.), common hornbeam (Carpinus betulus L.) and common ash (Fraxinus excelsior L.). There is wild undergrowth between the trees. The most trees can be found near the fortifications. The plantings copy the shape of the fortifications. They form an alley on theembankments and the plantings on the circumference of the bastions form small squares. The trees are well preserved. In the remaining part of the area under study black alders (Alnus glutinosa L.) predominate in a single-row planting along the old moat. The species composition and layout of the trees indicate that they were planted by man. The area was inventoried with four methods:

site measurement of trees in the area under study and marking them simultaneously on a site map. As a result of precise geodesic measurements landmarks, such as fences, buildings, etc. were marked on the map and used as a reference base.

proper green space inventory, which included detailed data about the green space, i.e. a list of tree and shrub species (Latin names), forms of occurrence of trees and shrubs (individual items, clusters, rows), estimated tree height (metres), the diameters of the crowns of standalone trees(metres), the state of preservation of existing green space.

photographic documentation of the area under study with its characteristic elements and nearest surroundings;

electronic processing of the inventory results by marking the items on a digital map, making a visualisation and section of the area.

The inventory was based on the nomenclature used in 'Dendrologia' by Włodzimierz Senetaand Jakub Dolatowski, published in 2008.

Green space design

The design of green space in the park consists of the existing part, i.e. intensive tree stands growing in the place of historical ground fortifications, and the planned part - located on the other side of the old moat. According to the plan, a few trees will be removed from the historical part because they grow in the line of planned paved pedestrian walkways and lower branches of existing trees will be cut. Smaller and self-sown trees will be removed. The trees whose lower branches will be cut grow chiefly in the direct neighbourhood of pedestrian walkways or on the slopes and foreground of the fortifications. By cutting their branches there will 
be better visibility in the pedestrian walkways and the bastions will be better exposed. We have planned plantings in the other part of the park so that the new vegetation will naturally enhance the character of the place. The planned flowerbeds will make a ribbon-like belt stretching along the old moat, thus enhancing the historical spatial arrangement and simultaneously making the indirect composition of the second level of plants located between the lowest level of lawns and the highest level of trees growing in the fortifications. The heights, forms, habits and colours of the plants forming the ribbon-like composition will also be diversified so that the natural, historical character of the foreground of thefortifications can be restored. The following plant species will grow in that place: Amur silver grass (Miscanthus sacchariflorus), gold-edged prairie cordgrass (Spartina pectinata 'Aureomarginata'), purple loosestrife (Lythrum salicaria), dotted loosestrife (Lysimachia punctata), white-flowered Greek valerian (Polemonium caeruleum $f$. Album), meadowsweet (Filipendula ulmaria), purple willow 'Nana' (Salix purpurea 'Nana') (Fig. 5).

Vegetation irrigation system

An irrigation system will be installed only in the part of the park with ornamental plantings in the form of a ribbon-like belt running parallel to the bed of the old moat. The automaticirrigation system in the ornamental part of the park will consist of four sections controlled by a system of low-voltage solenoid valves. The system of solenoid valves in a plastic casing will be placed in the ground near a transformer station at a depth of $40 \mathrm{~cm}$. The system of solenoid valves and sections will be controlled by means of a programmable time controller placed in the power supply box of the wholeirrigation system. There will be noautomaticirrigation system inthe other part of the park because it will be used for mass events and active recreation and it has a natural grass cover in the meadow which can be periodically irrigated with generally available devices used by services responsible for maintenance of the area.

Water aeration

Water exchange in the existing section of the old moat, which is about $700 \mathrm{~m}$ long, is difficult because part of the moatis filled near the connection to the Wieprza River. This situation resulted in contamination of the water in the moat and a water aeration system had to be designed. The system is supposed to improve oxygenation in the moat. In summer it will affect theself-cleaning of water, whereas in winter it will enable the maintenance of ice holes on each aeration spot, which will help the waterfowl living in the park to survive winter. Water will be aerated at six evenly spaced spots in the moat by means of side channel blowers poweringgrid segments with a 'floating island' and grid segments with a buoy. 'Floating islands' will also be additional facilities for the waterfowl. In consequence, natural values of the park space will be restored. The blowers will be powered from the existing transformer station by means of a three-phase underground electrical installation.

Park lighting system

The park lighting system will consist of tall and short lamp posts and floodlights. The historical part of the park will be lit by 13 short lamp posts standing along the park path running on the crown of the existing groundfortifications and by 9 tall lamp posts standing on the bastion platforms. This part of the park will also be illuminated by floodlights placed outside the outline of fortifications. The floodlights will illuminate the fortifications (bastions) and tall vegetation forms on the fortifications from the ground level. The remaining area of the park will be illuminated by 37 tall lamp posts standing along park paths.

Communication system

The communication system is an essential element of spatial composition. One of the most important technical elements of spatial composition is path routing. Paths will run along curved lines composed of straight lines and large-radius arches. The curves will be arranged similarly to the existing terrain, e.g. the lines of the riverbank and moat bank as well as the grade line, where planned gradients are similar to the existing gradient of the terrain. There will be large-radius horizontal arches in the stretches forming characteristic arrangements and 
there will be external arches with a five-metre radius on crossroads. We assumed $2 \%$ cross slopes for paths and planes of squares in cross sections of the road.

Type of surface. The following types of surface will be used in paths and squares: grey granite setts sized $7 \times 9 \mathrm{~cm}$ with a black or dark grey pattern and kerbs on edges. On the crown of embankments ' $L$ '-type prefabricated elements will be used to stabilise the surface and drainage system. The maximum load assumed for the surface of most paths is the same as for pedestrian traffic, whereas the maximum load for four-metre-wide peripheral paths is the same as the load of a vehicle with the maximum permissible laden weight of 3.5 tonnes. This will enable the vehicles of technical and maintenance services to drive on the paths. The drainage system of the walkway complex will be a natural flow from the paved surface onto adjacent unpaved areas down the cross and longitudinal slopes of the walkway surface. The suggested surface pattern is connected with the history of the place and it is based on the contemporary convention of interpreting historical elements - it is an image of a defensive wall with embrasures. The suggested image of embrasures consists of insets in the form of stripes of different sizes and free layout of black or dark grey setts on the plane of light grey setts. The suggested pattern and colours were designed as a modular, recurring segment of the walkway and as a separate pattern of the crown of the bastion based on its pentagonal plan. The designed pattern consists of five planes and it is perpendicular to external edges of the bastion [Fig. 5].
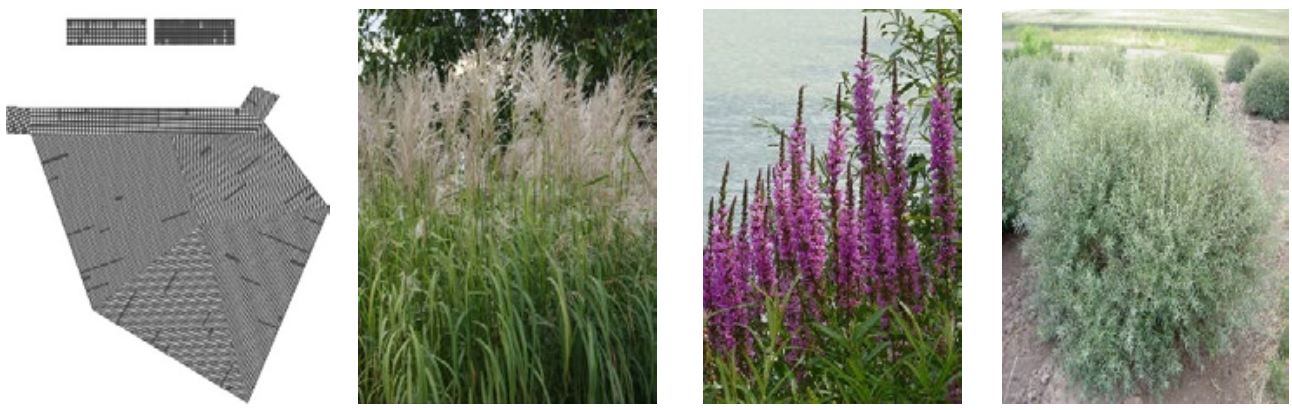

Fig. 5. (from the left) A pattern ofthe bastion flooring and pavement, grey and blackgranite setts sized $9 \times 7 \mathrm{~cm}$,. Examples of plants used in the ribbon-like composition - a decorative belt along the old moat: purple loosestrife (Lythrum salicaria), Amur silver grass (Miscanthus sacchariflorus), purple willow 'Nana' (Salix purpurea 'Nana'), source: a fragment of the plan of development of the

Park behind the Marine School in Darłowo, Town Council of Darłowo. Szumigała P. (2012a).

Ryc. 5. (od lewej) Wzór posadzki bastionu i chodnika, kostka granitowa 9/7 cm, szara i czarna. Przykłady rośliny zastosowanych w kompozycji wstęgi - ozdobnego pasa wzdłuż starej fosy: Lythrum salicaria - Krwawnica pospolita, Miscanthus sacchariflorus - Miskant cukrowy, Salix purpurea ,Nana' - Wierzba purpurowa w odm. ,Nana', źródło: fragment Projektu zagospodarowania Parku za Szkołą Morską w Darłowie, Urząd Miejski w Darłowie. Szumigała P. (2012a).

\section{STREET FURNITURE ITEMS}

According to the park development plan, there will be 122 items of street furniture: 25 benches, 25 dustbins, 5 bins for dog excrements, 3 information boards, 1 system playground, 1 board with the playground regulations, 46 tall lampposts $(4.5 \mathrm{~m}), 13$ short lamp posts $(1.0 \mathrm{~m})$ and a few artistic forms according to suggested solutions. Most of the street furniture will consist of products manufactured by Ziegler, Saternus, Thorn and Lappset. The pattern of paved surfaces and the style of street furniture were approved by the Voivodeship Conservation Officer in Koszalin.

Investment staging and cost estimate 
According to the plan, the investment will be divided into stages. The costs of the investment were shown in estimates. The investment was divided into two stages, according to the client's possibilities (the Town Council of Darłowo) to acquire EU funds. The first stage will involve making the technical infrastructure, i.e. the electrical installation of the lighting system, automatic moat irrigation and aeration systems, preparing unpaved walkways, cutting 8 trees, installing street furniture and lighting and planting vegetation. During the second stage the walkways and square will be paved. The cost of the park development was estimated at a gross value of 7 million zlotys.

The technical issues related with the construction of roads and other elements of park development included in the technical documentation were not described here due to the character of this presentation.

\section{SUMMARY}

The article presents the park development plan with elaborations concerning the issues related with the composition, conservation, landscape, materials, branch and execution of the investment. It is a complex elaboration concerning execution of the plan, which received the required approvals and permissions. The main problem in the design was to allow for historical conditions and guidelines of the conservation officer when adapting the ground fortifications to scenic and recreational functions. The design work resulted in a complex technical documentation, which will enable development of the area into a town park, whosescenic values will be similar to natural. The remains of historical fortifications were successfully incorporated into the programme of usable (leisure and recreational) functions available to the general public and adapted to the inhabitants' needs. The design of the park has a diversified spatial functionality programme. It consists of seven zones for users of different ages and the zones enable both active and passive leisure and recreation. The proposed remedy and investment programme lets us think that the preserved fragment of the ground fortifications, which is an important element of cultural heritage, will still exist in the urban landscape of Darłowo. The documentation prepared for the project gives a possibility to acquire external funds (from the EU and other sources). The funds will help to protect the physical condition of the place and use the attractiveness of its forms and values to organise an attractive urban space with an individual character.

\section{BIBLIOGRAPHY}

An 1897 German map of Rügenwalde. Western Poland Map Archive

History of Fortifications in the $19^{\text {th }}$ Century - New Prussian Fortresses, source: http://www.fort.mariwoj.pl/2020.htm source:http://amzpbig.com/maps/1564_Rugenwalde_agronomische_1897.jpg

Szumigała P., 2012. A Plan of Development of the Park Behind the Marine School in Darłowo, the Town Council of Darłowo.

Szumigała P., 2012. A Concept of Development of the Park Behind the Marine School in Darłowo, the Town Council of Darłowo.

The guidelines of the Voivodeship Conservation Officer in Koszalin, Koszalin 2012.

The Local Spatial Development Plan for the Town of Darłowo - Resolution No. XLVII/445/06 of the Town Council of Darłowoof 27 March 2006 